\author{
Arkadiusz Sieroń \\ Uniwersytet Wrocławski \\ sieron.arkadiusz@gmail.com
}

\title{
Znaczenie efektu Cantillona w teorii ekonomii*
}

\author{
JEL Classification: B53, D31, E00, E14, E31, E32, E51, E52, E58, G12, H11
}

Keywords: Cantillon effect, theory of money and inflation, theory of banking and central banking, theory of business cycles and price bubbles, theory of income distribution and income and wealth inequalities, public choice theory.

\section{Abstract}

\section{The Role of Cantillon Effect in Economics}

The aim of this article is to examine the role of the Cantillon effect in economics. The literature of economic theory lacks the detailed discussion of the implications of the first-round effect for economics. This paper attempts to fill this gap. The article is mainly theoretical, but considerations presented are illustrated by relevant empirical data. Based on the analysis, the author concludes that the effect of Cantillon develops particularly the theory of money and inflation, the theory of banking and central banking, the theory of business cycle and price bubbles, the theory of income distribution and income and wealth inequalities, and the theory of public choice.

\section{Wprowadzenie}

W poprzednich naszych artykułach zbadaliśmy pojęcie neutralności pieniądza (Sieroń, 2014), istotę efektu Cantillona (Sieroń, 2015a) oraz jego klasyfikację (Sieroń, 2015b). Choć w tych dwóch ostatnich tekstach omówiliśmy teoretyczne aspekty efektu pierwszej rundy i naszkicowaliśmy jego wkład w teorię ekonomii, w tej publikacji pragniemy w bardziej systematyczny sposób przeanalizować jego aplikacje w teoriach ekonomicznych.

* Artykuł powstał na podstawie przygotowywanej pod opieką prof. Witolda Kwaśnickiego oraz dra Mateusza Machaja rozprawy doktorskiej pt. Skutki wzrostu podaży pieniadza z punktu widzenia efektu Cantillona. 
Celem tego artykułu będzie zatem wskazanie i opisanie wkładu efektu Cantillona, czyli zmian w dystrybucji dochodu i majątku i w konsekwencji — w strukturze relatywnych cen oraz produkcji, zachodzących na skutek nierównomiernych zmian w podaży pieniądza (Sieroń, 2015a), w rozwój różnych subdziedzin ekonomicznych, takich jak: teoria pieniądza i inflacji, teoria bankowości i bankowości centralnej, teoria cyklu koniunkturalnego i baniek cenowych, teoria podziału dochodu i nierówności dochodowo-majątkowych oraz teoria wyboru publicznego. W literaturze brak bowiem takiego systematycznego opracowania. Praca ta będzie miała przede wszystkim charakter teoretyczny, niemniej zaprezentowane rozważania będą ilustrowane danymi. Przedstawione rozważania i dane dowodzą, że efekt pierwszej rundy ma istotne znaczenie dla gospodarki i teorii ekonomii. Badanie wzrostu podaży pieniądza, przeprowadzane w duchu Cantillona, stanowi niezwykle płodne poznawczo podejście do analizowania zmian w podaży pieniądza, które może wyjaśnić wiele zjawisk gospodarczych.

Artykuł jest zorganizowany w następujący sposób. W kolejnych rozdziałach badamy znaczenie efektu Cantillona dla teorii pieniądza i inflacji (rozdział 2), teorii bankowości i bankowości centralnej (rozdział 3), teorii cyklu koniunkturalnego i baniek cenowych (rozdział 4), teorii podziału dochodu i nierówności dochodowo-majątkowych (rozdział 5) oraz teorii wyboru publicznego (rozdział 6). Pracę zamyka podsumowanie.

\section{Teoria pieniądza i inflacji}

Przede wszystkim efekt pierwszej rundy wzbogaca mechanistyczną wersję ilościowej teorii pieniądza. Cantillon zgadzał się, że wzrost podaży pieniądza przekłada się na wzrost cen, ale krytykował Locke’a, że nie pokazał on, w jaki sposób nowe pieniądze rozprzestrzeniają się po gospodarce i w jakim stopniu wzrost podaży pieniądza przekłada się na wzrost cen:

Pan Locke stawia, jako podstawowe twierdzenie, że stosunek ilości dóbr i towarów do ilości srebra reguluje ceny rynkowe. Starałem się wyjaśnić tę myśl jego w poprzedzających rozdziałach: odczuł on dobrze, że obfitość pieniądza czyni wszystko droższym, ale nie starał się określić sposobu, w jaki się to odbywa. Wielka trudność tych poszukiwań polega na ustaleniu, jaką drogą i w jakim stosunku zwiększenie się ilości pieniądza podnosi ceny wszystkich rzeczy (Cantillon, [1755] 1938, s. 140-141).

Według Hayeka ([1935] 2014a, s. 165) Cantillon w swojej analizie przedstawił pierwszą ,próbę prześledzenia rzeczywistego łańcucha przyczynowo-skutkowego między ilością pieniądza a cenami”, zwracając uwagę na zróżnicowane oddziaływanie wzrostu podaży pieniądza na ceny w zależności od jego charakteru. Efekt ten - nazwany później przez Blauga (2000) „efektem Cantillona” — pokazuje zatem, że dla gospodarki znaczenie ma nie tylko sam ilościowy wzrost podaży pieniądza, ale także sposób, w jaki on zachodzi. 
Ponadto efekt Cantillona sprawia, że pieniądz nie jest neutralny, i to nawet w długim okresie. Aby bowiem zmiany w podaży pieniądza wpływały wyłącznie na zmienne nominalne, nowe pieniądze powinny równocześnie i proporcjonalnie zwiększać salda gotówkowe wszystkich osób. Jak jednak wykazał Cantillon w swojej analizie efektu pierwszej rundy, nowe pieniądze wprowadzane są do gospodarki poprzez określone kanały i rozchodzą się po niej sekwencyjnie, podbijając ceny stopniowo i w różnej proporcji. Prowadzi to do dystrybucji dochodu oraz zmian w strukturze relatywnych cen i produkcji, ponieważ na wzroście ilości pieniądza relatywnie skorzystają jego pierwsi odbiorcy (tj. osoby, których dochody wzrosną wcześniej, przy jeszcze względnie niezmienionych cenach), natomiast późniejsi odbiorcy poniosą względne straty. Jak zatem widać, efekt Cantillona rozwija także teorię podziału dochodu oraz teorię inflacji, podkreślając jej redystrybucyjny charakter (od późnych do wczesnych odbiorców nowych pieniędzy).

Innymi słowy, efekt Cantillona podważa przekonanie, według którego poziom cen zmienia się w tym samym stopniu co podaż pieniądza. Pokazuje on także, że wzrost podaży pieniądza oddziałuje na ceny i produkcję nawet wtedy, gdy ogólny poziom cen pozostaje stabilny, co pociąga za sobą niebagatelne implikacje dla polityki monetarnej (Hayek, [1935] 2014a).

Rola czynników pieniężnych w gospodarce stanowi jedno z kluczowych zagadnień ekonomicznych. Teorię ekonomii, w tej fundamentalnej debacie, znacznie wzbogaciłoby uwzględnienie efektu Cantillona, który powoduje, że pieniądz nie jest neutralny. Hayek ([1935] 2014a) uważał, że Cantillon swoją mikroekonomiczną analizą wpływu wzrostu ilości pieniądza na decyzje jednostek zapoczątkował drugi etap rozwoju teorii pieniądza po prostej ilościowej teorii pieniądza skupiającej się na dużych agregatach, takich jak ogólny poziom cen. Według niego postęp w dziedzinie teorii pieniądza będzie polegał na odrzuceniu konceptu „ogólnego poziomu cen" oraz na zwróceniu się ku badaniu przyczyn zmian w strukturze relatywnych cen. Podobne stanowisko zajął Morgenstern (1972), który badanie agregatów takich, jak „ogólny poziom cen” uznał za „krok wstecz” oraz postulował skupienie się na badaniu tego, w jaki sposób nowy pieniądz wchodzi do gospodarki.

Zróżnicowanie wpływu zwiększenia ilości pieniędzy na gospodarkę w zależności od jego sposobu przemawia także za bardziej zdezagregowaną analizą zjawisk pieniężnych, wyróżniającą różne typy polityki monetarnej czy polityki bilansowej banków komercyjnych.

\section{Teoria bankowości i bankowości centralnej}

Teoria bankowości i bankowości centralnej jest kolejnym obszarem teorii ekonomii, który mógłby wiele zyskać na uwzględnieniu efektu Cantillona. Jeśli chodzi o bankowość centralną, to należy przede wszystkim zauważyć, że banki centralne mogą w różny sposób prowadzić politykę monetarną i kreować bazę monetarną, 
co niejednorodnie wpływa na ekspansję kredytową i w konsekwencji na przebieg cyklu koniunkturalnego.

Przykładowo, luzowanie ilościowe stanowi odmienną metodę wprowadzania nowych pieniędzy do gospodarki w stosunku do tradycyjnych operacji otwartego rynku, generując nieco inny efekt pierwszej rundy. O ile bowiem w operacjach otwartego rynku nabywane są najczęściej krótkoterminowe skarbowe instrumenty dłużne, o tyle luzowanie ilościowe może zachodzić poprzez kupowanie także długoterminowych obligacji, w tym również tych nieskarbowych (np. obligacji korporacyjnych lub obligacji zabezpieczonych hipotekami) (Bowdler, Radia, 2012). Pociąga to za sobą odmienne skutki dystrybucyjne, inaczej wpływając także na krzywą dochodowości oraz premię za ryzyko. Przykład ten pokazuje, że warto analizować politykę monetarną w bardziej szczegółowy i zdezagregowany sposób zgodnie z duchem pionierskiej analizy Cantillona.

Uwzględnienie efektu pierwszej rundy mogłoby także wnieść pewną wartość dodaną do debaty na temat skutków (zbyt) luźnej polityki monetarnej, w tym tej niekonwencjonalnej. Efekt Cantillona stanowi bowiem jedną z przyczyn, dla których polityka monetarna prowadzi do redystrybucji dochodu i majątku obywateli (mimo braku legitymizacji do podziału dochodu między jednostkami, jak w przypadku polityki fiskalnej), która może powiększać nierówności dochodowo-majątkowe. Szczególnie silne kontrowersje wzbudza niestandardowa polityka monetarna. Głównym kanałem transmisji luzowania ilościowego ma być bowiem tzw. efekt bilansowania portfela inwestycyjnego, który polega na tym, że sprzedawcy papierów wartościowych będą chcieli przywrócić stare (przed transakcją z bankiem centralnym) proporcje między gotówką (depozytami bankowymi) a aktywami finansowymi i w tym celu będą nabywać inne aktywa finansowe, zwiększając ich ceny i zmniejszając rentowności. Niższe koszty pożyczkowe (czy emisji nowych akcji) oraz tzw. efekt bogactwa mają pobudzić wydatki oraz inwestycje. Jak widać, banki centralne są świadome, że wzrost podaży pieniądza prowadzi do wzrostu dochodu jego pierwszych odbiorców, co — w rezultacie wzrostu zasobów pieniężnych i spadku krańcowej użyteczności jednostki pieniężnej — spowoduje wzrost ich wydatków. Banki centralne zauważają także, że wzrost cen aktywów spowoduje wzrost bogactwa części jednostek (posiadaczy tychże aktywów), co według nich będzie powodować wzrost wydatków i ożywienie gospodarcze. To, czego jednak banki centralne zdają się nie dostrzegać (lub ignorują to), to fakt, że na wzroście podaży pieniądza, spadku stóp procentowych i cen wybranych aktywów finansowych będzie korzystać wyłącznie część społeczeństwa. Ci, do których nowe pieniądze trafią później — wierzyciele oraz osoby nieposiadające aktywów, których ceny rosną na skutek luzowania ilościowego - będą w gorszym położeniu. Innymi słowy, wzrost cen aktywów (czy jakichkolwiek dóbr lub usług) nie jest w stanie zwiększyć społecznego bogactwa, lecz prowadzi jedynie do (re)dystrybucji dochodu i majątku — zgodnie z efektem Cantillona. Choć banki centralne dostrzegają korzyści jednych osób, to jednak zapominają o tych, którzy tracą na wzroście cen 
aktywów, czyli o osobach, których nie stać na ich zakup ze względu na wzrost cen (Hülsmann, 2013) lub mają ograniczony dostęp do rynków kapitałowych i nie mogą emitować papierów wartościowych oprocentowanych tak nisko, jak mogą czynić to niektóre, na ogół większe i zamożniejsze podmioty gospodarcze.

Dokładna analiza efektu pierwszej rundy kreacji pieniędzy przez banki centralne oraz redystrybucyjnych efektów wzrostu podaży pieniądza może zatem zwiększyć nasze zrozumienie skutków polityki monetarnej oraz zjawisk koniunkturalnych (Raskin, 2013).

Jeśli chodzi o teorię bankowości komercyjnej, to pośród badaczy istnieje konsensus, że banki komercyjne kreują depozyty i tym samym większość podaży pieniądza we współczesnych gospodarkach (McLeay et al., 2014). Ekonomiści nie są jednak zainteresowani badaniem tego, w jaki sposób banki komercyjne wprowadzają nowe pieniądze do gospodarki, skupiając się na analizie dużych agregatów. Tymczasem różnice w metodach kreacji depozytów bankowych mają istotne znaczenie dla gospodarki i cyklu koniunkturalnego. Banki komercyjne mogą tworzyć depozyty poprzez przyznawanie kredytów, jak i kupno aktywów. Ponadto banki komercyjne udzielają różnego typu kredytów oraz nabywają rozmaite aktywa. Jak wykazaliśmy w innym artykule (Sieroń, 2015c), banki komercyjne swoją polityką inwestycyjną i decyzjami dotyczącymi struktury aktywów wpływają na przebieg cyklu koniunkturalnego. Przykładowo, udzielanie znacznej ilości kredytów hipotecznych może prowadzić do boomu na rynku nieruchomości i relatywnego rozrostu sektora budowlanego względem całej gospodarki, efektu bogactwa, redukcji mobilności pracowników oraz niższej płynności banków i większego nawisu długu — zjawiska te nie muszą zaistnieć (lub mogą zaistnieć w mniejszym stopniu) w przypadku udzielania przez banki innych kredytów lub nabywania papierów wartościowych.

Jak zatem widać, różnice w polityce inwestycyjnej banków komercyjnych, a więc to, jak nowe pieniądze wprowadzane są do gospodarki (w obrębie ekspansji kredytowej), odpowiadają w istotnej mierze za tzw. wtórne cechy cykli koniunkturalnych.

Ponadto zdezagregowana analiza kreacji nowych pieniędzy i kredytu w duchu analizy Cantillona mogłaby nie tylko wzbogacić ekonomię głównego nurtu, ale także i szkołę austriacką. Austriacka teoria cyklu koniunkturalnego powinna zostać rozszerzona o zmiany, jakie zaszły we współczesnej bankowości. Po pierwsze obecnie nie tylko banki komercyjne mogą kreować kredyt. We współczesnej gospodarce szczególnie istotna wydaje się kreacja pieniądza przez tzw. równoległy system bankowy — znaczna część kredytów udzielana jest w celu ich konwersji na papier wartościowy albo w ogóle przez inne podmioty niż banki komercyjne. Sekurytyzacja pozwala tradycyjnym bankom komercyjnym na zwiększanie akcji kredytowej, zaś pośrednictwo zobowiązań umożliwia bankom cienia kreację kredytu przez nie same (Claessens et al., 2012). Po drugie od czasów Mises'a czy Hayeka zaszły istotne zmiany w strukturze kredytów 
udzielanych przez banki komercyjne. Według tradycyjnego ujęcia austriackiej teorii cyklu koniunkturalnego nowe pieniądze trafiają do gospodarki jako kredyty, które „przyznaje się zasadniczo z przeznaczeniem na procesy produkcji” (Huerta de Soto, 2009, s. 263). Obecnie jednak banki komercyjne udzielają przede wszystkim kredytów hipotecznych gospodarstwom domowym (Jordà et al., 2014). Wzrost znaczenia kredytów hipotecznych przyczynił się do powstania bańki cenowej na amerykańskim rynku nieruchomości w pierwszej dekadzie XXI w. oraz do wzrostu zadłużenia gospodarstw domowych, co może tłumaczyć relatywnie wolne tempo ożywienia gospodarczego po zakończeniu wielkiej recesji w $2009 \mathrm{r}$. (Jordà et al., 2014). Tendencja wzrostowa wartości udzielanych kredytów hipotecznych gospodarstwom domowym oznacza, że ekspansja kredytowa coraz rzadziej służy zwiększaniu zdolności wytwórczych poprzez inwestycje w kapitał rzeczowy — jak zakładał Hayek ([1935] 2014a) — lecz raczej wygładzaniu konsumpcji w cyklu życia lub celom spekulacyjnym związanym z oczekiwaniem wyższych cen istniejących już aktywów (Turner, 2010, s. 7). Zachodzące zmiany w strukturze kredytów udzielanych przez banki komercyjne mają zatem niebagatelny wpływ na tempo wzrostu gospodarczego i przebieg cyklu koniunkturalnego.

Warto więc analizować inflację monetarną (w tym ekspansję kredytową) w bardziej zdezagregowany sposób, śledząc dokładnie, kto i w jaki sposób kreuje nowe pieniądze oraz dokąd one trafiają, ponieważ taka zdezagregowana analiza wzrostu bazy monetarnej oraz zmian w strukturze aktywów banków komercyjnych może pomóc w lepszym zrozumieniu cyklu koniunkturalnego oraz wtórnych zjawisk mu towarzyszących, w tym baniek cenowych.

\section{Teoria cyklu koniunkturalnego i baniek cenowych}

Efekt Cantillona umożliwia pełniejsze zrozumienie zjawisk koniunkturalnych. Przede wszystkim jest on podstawą austriackiej teorii cyklu koniunkturalnego. Istotnie, o ile ekonomiści z innych szkół badawczych pochylają się nad takimi przyczynami nieneutralności pieniądza, jak sztywności cenowe (nowi keynesiści) bądź niepełna informacja (nowi klasycy), o tyle szkoła austriacka skupia się w swych analizach na efekcie pierwszej rundy. Austriacka teoria cyklu koniunkturalnego bada bowiem, w jaki sposób wzrost podaży pieniądza przez kanał kredytowy wpływa na strukturę relatywnych cen oraz produkcji. Według szkoły austriackiej cykl koniunkturalny wynika z tego, że nowe pieniądze wprowadzane są do gospodarki przez rynek pożyczkowy, co obniża rynkową stopę procentową i prowadzi do międzyokresowej nierównowagi w postaci wpierw nietrwałego boomu oraz późniejszego nieuchronnego kryzysu (O’Driscoll, Rizzo, 1996, s. 204-205). Jak zatem widać, analizuje ona pewien szczególny wariant efektu Cantillona. Według Misesa ([1949] 2007, s. 471) „Istotą teorii monetarnej [cyklu koniunkturalnego] jest to, że dostrzega ona, iż zmiany relacji pieniężnych spowo- 
dowane czynnikami pieniężnymi nie wywierają równomiernego, czyli jednoczesnego i jednakowego wpływu na ceny różnych dóbr, płace i stopy procentowe".

Warto zauważyć, że efekt Cantillona będzie zachodził także w wymiarze międzynarodowym. Innymi słowy, we współczesnej, globalnej gospodarce wzrost podaży pieniądza w jednym kraju (zwłaszcza w znacznej gospodarce w skali świata, emitującej walutę rezerwową, jak np. w gospodarce amerykańskiej) będzie prowadzić także do istotnych efektów dystrybucyjno-cenowych w innych krajach. Międzynarodowy efekt pierwszej rundy może zatem tłumaczyć obserwowaną synchronizację cyklu koniunkturalnego pomiędzy krajami (Bordo i Helbling, 2010), globalny charakter inflacji (Borio, Filardo, 2007), a także pewne cechy historycznych i współczesnych systemów monetarnych — analiza wzrostu podaży pieniądza $\mathrm{w}$ systemie monetarnym $\mathrm{z}$ walutami rezerwowymi pokazuje, że w wymiarze międzynarodowym kraj emitujący walutę rezerwową korzysta kosztem innych państw, ponieważ może nabywać od nich dobra za wykreowane pieniądze, które banki centralne innych państw utrzymują jako rezerwy.

$\mathrm{W}$ obecnym systemie monetarnym wzrost podaży pieniądza w jednym kraju będzie oddziaływał na inne kraje poprzez kanał handlowy (inflacja monetarna prowadzi do zmian w saldach pieniężnych i strukturze relatywnych cen, i w konsekwencji prowadzi do zmian w handlu zagranicznym), kanał stopy procentowej, kanał ryzyka, kanał kredytowy oraz kanał walutowy. Wprowadzanie nowych pieniędzy poprzez kanał kredytowy w kraju inicjującym inflację monetarną obniża $\mathrm{z}$ kolei stopę procentową $\mathrm{i}$ - zgodnie $\mathrm{z}$ arbitrażem procentowym — prowadzi do odpływu kapitału do innych gospodarek, wywołując także w nich zjawiska inflacyjne. Spadkowi stopy procentowej w znaczącej gospodarce światowej może również towarzyszyć poszukiwanie wyższych rentowności poprzez akceptowanie bardziej ryzykownych przedsięwzięć przez inwestorów. Ponadto, biorąc pod uwagę występowanie właściwie jednej globalnej struktury produkcji, obniżenie stopy procentowej w ważnym centrum finansowym, na skutek ekspansji kredytowej, będzie prowadzić do zaburzeń w globalnej strukturze produkcji (np. do nietrwałego boomu w krajach specjalizujących się w wytwarzaniu określonych dóbr). Ponieważ zaś współczesny system monetarny składa się z narodowych walut fiat o płynnych kursach, ekspansja kredytowa będzie prowadzić nie tylko do zmian w poziomie stóp procentowych, ale także kursów walutowych, powodując w gospodarce zaburzenia zarówno wertykalne, jak i horyzontalne. Nieuwzględnianie globalnych czynników inflacyjnych może powodować, że polityka banku centralnego będzie zbyt ekspansywna, co stanowi kolejny argument przeciwko (zbyt luźnej) polityce monetarnej.

Jak zatem widać, uwzględnienie międzynarodowego efektu Cantillona rozwija i rozszerza badania nad międzynarodowym cyklem koniunkturalnym oraz międzynarodowymi systemami walutowymi, prowadząc do niezmiernie ważnych wniosków dla teorii ekonomii oraz polityki monetarnej. Wbrew wielu opiniom narodowe waluty fiat nie izolują od globalnych procesów inflacyjnych 
oraz cykli międzynarodowych (Hayek, [1937] 2014b). We współczesnej globalnej gospodarce dany kraj - zwłaszcza jeśli jest to mała i otwarta gospodarka - może doświadczać procesów inflacyjnych i cyklu koniunkturalnego, nawet gdy prowadzi on relatywnie restrykcyjną politykę monetarną. Adalid i Detken (2007) uważają nawet, że wzrost globalnej podaży kredytu stanowi lepszy prognostyk kryzysów finansowych niż krajowa podaż kredytu i stopa inflacji cenowej. Międzynarodowy efekt Cantillona można też traktować jako (oficjalnie) niezamierzoną konsekwencję ekspansji monetarnej w znaczących gospodarkach światowych (zwłaszcza w Stanach Zjednoczonych dzięki dominującej pozycji dolara amerykańskiego jako waluty rezerwowej), co stanowi kolejny argument przeciwko (zbyt) luźnej polityce monetarnej (ustalanej zwłaszcza w oparciu o wyłącznie krajowe zmienne, takie jak stopa inflacji cenowej), szczególnie tej prowadzonej przez najistotniejsze gospodarki na świecie. Zatem międzynarodowe przepływy kapitału — stanowiące przejaw sekwencyjnego rozchodzenia się pieniędzy po światowej gospodarce - osłabiają skuteczność krajowych polityk monetarnych, ponieważ banki centralne nie mają bezpośredniego wpływu na podaż kredytu udzielanego przez zagraniczne podmioty czy na międzynarodowych rynkach kapitałowych (pomijając kontrolę kapitału, która jest radykalnym narzędziem). $Z$ drugiej strony ze względu na globalne rozchodzenie się nowych pieniędzy w światowej gospodarce inflacja monetarna w danym kraju nie musi spowodować w nim (relatywnie szybkiego) wzrostu cen, jeśli nowo wykreowane pieniądze trafią najpierw na zagraniczne rynki. Zatem określony sposób realizacji inflacji monetarnej - polegający na tym, że nowe pieniądze trafiają w znacznej mierze za granicę - może tłumaczyć, dlaczego wzrost podaży pieniądza nie musi prowadzić do znacznej krajowej inflacji cenowej. W podobny sposób ekspansja kredytowa w danym kraju nie musi spowodować w nim intensywnego cyklu koniunkturalnego, jeśli nowo wykreowane pieniądze zostaną zainwestowane za granicą. Innymi słowy, przepływy kapitału łagodzą cykl koniunkturalny w kraju eksportującym kapitał i powodują lub intensyfikują go w kraju przyjmującym. Potwierdza to zasadność badania efektu Cantillona i tego, w jaki sposób nowe pieniądze trafiają do gospodarki.

Efekt pierwszej rundy może także tłumaczyć powstawanie baniek cenowych (spekulacyjnych, na rynkach aktywów) czyli sytuacji, w której ceny aktywów odrywają się od ich wartości fundamentalnej (Scherbina, 2013). Tworzenie się baniek na rynkach aktywów jest bowiem najlepszym dowodem na to, że ceny różnych dóbr i usług w gospodarce nie wzrastają równomiernie, zgodnie z Friedmanowskim modelem helikoptera (Friedman, 1969), lecz raczej nierównomiernie, tak jak opisał to Cantillon. Bańka spekulacyjna oznacza bowiem sytuację, w której ceny na danym rynku wzrosły nadmiernie, w znacznie większym stopniu niż na innych rynkach. Przewartościowanie jednych aktywów oznacza z konieczności niedowartościowanie innych. Relatywny wzrost cen aktywów wynika z ekspansji kredytowej, czyli z określonej realizacji efektu Cantillona. 
Ekonomiści ze szkoły austriackiej tradycyjnie upatrują przyczyny niezrównoważonych zaburzeń strukturalnych $\mathrm{w}$ gospodarce (wliczając $\mathrm{w}$ to nadmierny wzrost określonych aktywów czy nawet bańki cenowe) w ekspansji kredytowej (Skousen, 2011). Ekspansja kredytowa obniża bowiem stopę procentową, co prowadzi do relatywnego wzrostu cen aktywów (jako silniej reagujących na zmiany stóp procentowych) względem dóbr konsumpcyjnych. Ponadto banki komercyjne udzielają także kredytów przeznaczanych bezpośrednio na zakup danych aktywów. Ciągły napływ kapitału na dany rynek może zatem — zgodnie z efektem Cantillona - doprowadzić do bańki cenowej. Jak zauważa Thornton (2006), efekty inflacji monetarnej będą się różnić w zależności od tego, gdzie napływa nowo wykreowany pieniądz. W szczególności na tych rynkach, dokąd trafia w pierwszej kolejności, może uformować się bańka spekulacyjna. Innymi słowy, system bankowy kreuje środki pieniężne, których dopływ jest niezbędny do stworzenia bańki, jednak o tym, na którym rynku ona powstaje, decydują wydatki jednostek.

W literaturze głównego nurtu również coraz częściej wymienia się czynniki monetarne jako nierozerwalnie związane z tworzeniem się baniek spekulacyjnych (np. Bordo, Landon-Lane, 2013). Podkreśla się także, że wzrost podaży pieniądza i kredytu, oraz w konsekwencji cen aktywów, może prowadzić do nierównowagi gospodarczej nawet przy niskim wskaźniku cen towarów i usług konsumpcyjnych (Borio, Lowe, 2002).

Ekonomiści głównego nurtu pomijają jednak w swoich analizach efekt pierwszej rundy, który tłumaczy, dlaczego dochodzi do baniek cenowych. Gdyby pieniądze wpływały do gospodarki równomiernie ( $\mathrm{tj}$. $\mathrm{w}$ taki sposób, który nie oddziałuje w tej samej proporcji i w tym samym czasie na salda gotówkowe wszystkich podmiotów gospodarczych), takie zjawisko byłoby niemożliwe. W rzeczywistości jednak nowe pieniądze wprowadzane są do gospodarki poprzez określone kanały (także w ramach ekspansji kredytowej). Cena tych aktywów, na których koncentruje się popyt pieniężny i na które w pierwszej kolejności nowo wykreowane pieniądze są wydawane, będą wzrastać najbardziej. W krańcowym przypadku ciągły dopływ środków pieniężnych na dany rynek przy współdziałaniu odpowiednich czynników instytucjonalnych (np. pokusy nadużycia) oraz psychologicznych (np. oczekiwań dalszych wzrostów cen) może doprowadzić do powstania bańki spekulacyjnej. Taka realizacja efektu Cantillona prowadzi do odmiennego schematu dystrybucji dochodu i majątku oraz w większym stopniu zagraża stabilności finansowej i może prowadzić do głębszej recesji w porównaniu do ekspansji kredytowej, której nie towarzyszy bańka spekulacyjna. Chociaż ceny aktywów odgrywają ważną rolę w transmisji monetarnej (Mishkin, 2001), to jednak banki centralne nie biorą pod uwagę inflacji cen aktywów (a przynajmniej nie explicite). W literaturze od dawna toczy się dyskusja na ten temat (Bordo, Wheelock, 2004). Jeśli wzrost podaży pieniądza prowadzi do oderwania się cen aktywów od ich wartości fundamentalnych i jeśli korekta po pęknięciu bańki przyczynia się do dłuższej i poważniejszej recesji, to jest to kolejny argument 
przeciwko luźnej polityce monetarnej. Wydaje się także, że w takiej sytuacji banki centralne powinny brać pod uwagę dynamikę cen aktywów. Skupianie się przez banki centralne wyłącznie na wskaźniku cen towarów i usług konsumpcyjnych może bowiem prowadzić do niedostrzeżenia przez nie wszystkich negatywnych konsekwencji ekspansji pieniądza i kredytu, w tym nierównowagi na rynku aktywów. Innymi słowy, w konsekwencji niedostrzegania tego, że nowe pieniądze mogą być wprowadzane do gospodarki nie poprzez rynek dóbr i usług konsumpcyjnych, lecz poprzez rynek aktywów i tam generować silne procesy inflacyjne, banki centralne mogą prowadzić zbyt luźną politykę monetarną prowadzącą do większej niestabilności finansowej.

\section{Teoria dystrybucji dochodu i nierówności dochodowych}

W ostatnim ostatnim czasie - $\mathrm{w}$ wyniku implementacji niekonwencjonalnej polityki monetarnej przez niektóre banki centralne po wybuchu kryzysu finansowego w 2008 r. oraz za sprawą publikacji Piketty’ego (2014) na temat nierówności dochodowo-majątkowych - wzrosło zainteresowanie tym, w jaki sposób inflacja oraz polityka monetarna, w tym niekonwencjonalna, wpływają na dystrybucję dochodu i oddziałują na nierówności dochodowo-majątkowe. Literatura przedmiotu w zdecydowanej większości pomija efekt Cantillona, skupiając się innych aspektach inflacji oraz polityki monetarnej. Przykładowo, ekonomiści często traktują inflację jako regresywny podatek na gotówkę (Erosa, Ventura, 2002) albo skupiają się na efektach inflacji w zależności od tego, czy jest ona oczekiwana, czy nie (np. Fischer, Modigliani, 1978), bądź analizują inflacyjną redystrybucję od pracowników do pracodawców czy od wierzycieli netto do dłużników netto (np. Laidler, Parkin, 1975), ignorując redystrybucję od późniejszych do wcześniejszych odbiorców nowych pieniędzy.

Uwzględnienie efektu pierwszej rundy w analizie związku między inflacją monetarną a podziałem dochodu i nierównościami dochodowymi-majątkowymi rozwija zarówno teorię inflacji, jak i teorię dystrybucji dochodu i nierówności dochodowo-majątkowych poprzez lepsze zrozumienie redystrybucyjnych efektów inflacji i polityki monetarnej. Biorąc pod uwagę opinie, że rosnące nierówności dochodowo-majątkowe mogą ograniczać tempo wzrostu gospodarczego (Ostry et al., 2014), wiązać się z większą niestabilnością finansową (Kumhof et al., 2013) oraz oddziaływać na mechanizm transmisji polityki pieniężnej (Mersch, 2014), włączenie efektu Cantillona do analizy nierówności dochodowo-majątkowymi wydaje się jak najbardziej wartościowym pomysłem.

Efekt pierwszej rundy polega na (re)dystrybucji dochodu i majątku (oraz wynikających z niej zmian w strukturze cen i produkcji) w obrębie społeczeństwa zachodzącej w rezultacie tego, że podaż pieniądza wprowadzana jest do gospodarki 
wyłącznie poprzez określone kanały. Oznacza to, że część osób otrzymuje nowo wykreowane pieniądze wcześniej od innych, jeszcze przed powszechnym wzrostem cen, co zwiększa ich realny dochód i powiększa majątek. Efekt Cantillona wpływa zatem na podział dochodu w społeczeństwie, oddziałując na poziom nierówności dochodowo-majątkowych (Sieroń, 2017).

Podaż pieniądza nigdy bowiem nie wzrasta równomiernie, co prowadzi do zmian w strukturze relatywnych cen, cyklu koniunkturalnego i baniek spekulacyjnych. Okazuje się, że osoby relatywnie biedniejsze często tracą na takich zmianach względem osób bogatszych. Jest tak, ponieważ nie mają dostępu jako pierwsi do nowo wykreowanych pieniędzy, a do tego zmiany w strukturze relatywnych cen są dla nich stosunkowo niekorzystne (więcej procentowo wydają na bardziej drożejące dobra oraz posiadają więcej należności netto, zaś mniej aktywów, których ceny rosną podczas inflacji). Ponadto ekspansja kredytowa banków komercyjnych może powiększać nierówności dochodowo-majątkowe także poprzez udzielanie kredytów osobom relatywnie bogatszym, które mogą przedstawić bardziej wartościowe zabezpieczenie i odznaczają się wyższą wiarygodnością kredytową. Zatem, ponieważ zdolność kredytowa jest funkcją posiadanego majątku, zaś banki komercyjne w pierwszej kolejności udzielają kredytów osobom lub firmom o największej zdolności kredytowej, ekspansja kredytowa nieodłącznie wiążę się z pogłębianiem nierówności. Z kolei redystrybucja od wierzycieli do dłużników wspiera stosunkowo klasę średnią kosztem najbiedniejszych i najbogatszych, zaś na wzroście cen aktywów finansowych relatywnie zyskują najbogatsze gospodarstwa domowe.

Efekt Cantillona może powodować taką redystrybucję dochodu i majątku, która zwiększa nierówności dochodowe i majątkowe. Co ważne, ponieważ efekt pierwszej rundy sprawia, że pieniądz nie jest neutralny nawet $\mathrm{w}$ długim okresie, wpływ inflacji monetarnej na nierówności dochodowo-majątkowe będzie zachodził nie tylko w krótkim okresie, jako przejściowy efekt. Innymi słowy, jednym z (oficjalnie) niezamierzonych skutków inflacji monetarnej okazuje się taka redystrybucja dochodu i majątku, która w wielu aspektach prowadzi do wzrostu nierówności dochodowo-majątkowych.

W szczególności wzrost podaży pieniądza implikuje redystrybucję dochodu od późnych do wczesnych odbiorców nowych pieniędzy, którymi są relatywnie bogatsze podmioty z sektora finansowego. Wprowadzanie nowych pieniędzy poprzez określone kanały oznacza (re)dystrybucję dochodu do osób, które nowe pieniądze dostają jako pierwsze, od osób, do których te pieniądze trafiają później. Wynika to $\mathrm{z}$ tego, że pierwsi odbiorcy nowo wykreowanych pieniędzy mają ich więcej, zaś ceny jeszcze nie zdążyły się zmienić. Efekt ten może tłumaczyć rozrost sektora finansowego w ciągu ostatnich kilkudziesięciu lat w krajach rozwiniętych, który — za sprawą ekspansji kredytowej i transakcji z bankiem centralnym jest jednym z pierwszych odbiorców nowego pieniądza. Przykładowo, jego udział w amerykańskim PKB zwiększył się z 4,9 \% w 1980 r. do 7,9 \% w 2007 r., podczas gdy kapitalizacja giełdy wzrosła z 50 do $141 \%$ PKB (Greenwood, Scharf- 
stein, 2012). Wpływ na nierówności dochodowe wydaje się oczywisty. W $1980 \mathrm{r}$. przeciętny pracownik w sektorze finansowym zarabiał mniej więcej tyle samo, co pracownicy w innych sektorach, zaś w 2006 r. jego pensja była już średnio o 70 proc. wyższa niż w pozostałych sektorach (Greenwood, Scharfstein, 2012).

Jak widać, to inflacja monetarna i związany z nią efekt Cantillona, a nie mechanizm wolnorynkowy, mogą thumaczyć rozrost sektora finansowego w gospodarkach rozwiniętych na przestrzeni ostatnich kilkudziesięciu lat, który odpowiada do pewnego stopnia za wzrost nierówności dochodowo-majątkowych. Jest to niezmiernie ważne spostrzeżenie, biorąc pod uwagę, że według wielu badań nadmierny rozrost sektora finansowego może mieć negatywny wpływ na wzrost gospodarczy z powodu większej niestabilności gospodarki, obniżenia stopy oszczędności poprzez osłabienie bariery płynności gospodarstw domowych oraz inflacyjnej redystrybucji zasobów, które byłyby wykorzystywane w innych sektorach w bardziej produktywny sposób (Rzońca, 2014, s. 199-201).

\section{Teoria wyboru publicznego}

Teoria wyboru publicznego stosuje teorie i metody ekonomii do analizy zachowań politycznych (Shughart, b.r.). Uwzględnienie efektu Cantillona może pomóc w zrozumieniu niektórych zachowań ze sfery polityki i w ten sposób rozwinąć teorię wyboru politycznego. Przede wszystkim należy zauważyć, że polityka monetarna zasadza się na efektach dystrybucyjnych, gdyż neutralna polityka monetarna byłaby pozbawiona większego znaczenia, tak ekonomicznego, jak i politycznego (Wagner, 1986). Będzie to szczególnie prawdziwe w demokracji większościowej, w której polityka o charakterze dyskryminacyjnym jest chętniej wybierana przez polityków niż polityka niedyskryminacyjna, gdyż w ten sposób - tj. poprzez wspieranie (zmiany w strukturze relatywnych cen) wąskich grup interesów kosztem szerokiej rzeszy osób (korzyści są znaczne, zaś koszty w przeliczeniu na osobę niewielkie, co powoduje brak istotnego sprzeciwu społecznego) - mogą oni zyskać więcej głosów (Wagner, 1980).

Można także argumentować, że rządy były od zawsze zainteresowane kreacją pieniędzy, ponieważ inflacja monetarna - m.in. właśnie ze względu na efekt pierwszej rundy — odznacza się pewnymi przewagami względem opodatkowania, czyli drugiego podstawowego sposobu pozyskiwania funduszy przez rząd. Ma ona bardziej dyskryminacyjny charakter, dzięki czemu rządy mogą łatwiej osiągać konkretne cele i np. wspierać specjalne grupy interesu. Przy tym jest to mniej oczywisty sposób redystrybucji dochodu w porównaniu do opodatkowania - inflacja monetarna jest o wiele trudniejszym zjawiskiem do zanalizowania i niezmiernie trudno oszacować jej skutki, co wynika m.in. z tego, że nowo wykreowane pieniądze są wprowadzane do gospodarki przez wiele kanałów i prawdopodobnie nigdy w ten sam sposób. Poza tym inflacja monetarna relatywnie 
wspiera dłużników netto, do których zaliczają się także rządy i część przedsiębiorców. Ponadto wzrost podaży pieniądza może obniżyć stopę procentową, jeśli nowo wykreowane pieniądze zostaną wprowadzone do gospodarki przez szeroko pojęty rynek kredytowy, co wspiera rządy ze względu na niższe koszty obsługi długu publicznego i może wywołać wrażenie ogólnej prosperity. Co więcej, negatywne efekty inflacji monetarnej pojawiają się dopiero po pewnym czasie, podczas gdy korzyści z niej płynące dla określonych podmiotów są natychmiastowe. Musi bowiem upłynąc trochę czasu, zanim ceny powszechnie wzrosną, zmniejszając dobrobyt części społeczeństwa. Ta cecha inflacji monetarnej jest niezwykle ważna, gdyż powodując początkowo ożywienie, zaciemnia swoje negatywne skutki dla społeczeństwa.

Innymi słowy, z powodu efektu Cantillona inflacja monetarna może być postrzegana jako atrakcyjniejszy sposób generowania przez rządy dochodów niż opodatkowanie. Jest tak, gdyż stanowi ona bardziej dyskryminacyjną politykę, dzięki której można wspierać poszczególne podmioty i sektory, początkowo bez bezpośrednich, negatywnych skutków dotykających inne podmioty i sektory. Dzięki inflacji monetarnej rządy są w stanie przekazać pieniądze określonym jednostkom i zwiększyć ich nominalny dochód bez zabierania pieniędzy innym i obniżania ich dochodu nominalnego. Co więcej, inflacja monetarna może być łatwiejsza do przeprowadzenia z politycznego punktu widzenia, ponieważ nie wymaga uchwalenia odpowiedniej ustawy. Tworzy ona również wrażenie ogólnej prosperity, odwlekając negatywne skutki w czasie, które na dodatek nie są prawidłowo rozpoznane przez społeczeństwo. W przeciwieństwie do opodatkowania, może również obniżyć stopę procentową, a więc i koszt obsługi długu.

Ponadto z efektu Cantillona może częściowo wynikać fakt, dlaczego państwa tak często angażują się $\mathrm{w}$ wojnę, korzystają z pomocy zagranicznej i ją oferują czy dewaluują bądź deprecjonują waluty. Nawet jeśli prowadzenie wojny jest nieopłacalne w skali całej gospodarki, to z pewnością mogą na niej skorzystać rządzący. Jest tak, gdyż pozyskane ewentualnie środki pieniężne trafiają do sektora rządowego i sektorów blisko z nim związanych (głównie do sektora militarnego), zaś koszty prowadzenia wojny są rozproszone pomiędzy wielu członków społeczeństwa - w postaci przymusowej pracy (służby wojskowej) bądź w postaci wyższego opodatkowania lub inflacji cenowej na skutek kreacji pieniądza.

Podobnie rządowe zaangażowanie w pomoc zagraniczną wynika prawdopodobnie z efektu pierwszej rundy, tj. tego, że pieniądze nie trafiają do gospodarek państw rozwijających się równomiernie, lecz poprzez sektor rządowy i powiązane z nimi podmioty (Bauer, Yamey, 1983). Efekt Cantillona może tłumaczyć także wspieranie cen określonych aktywów bądź eksporterów poprzez wzrost podaży pieniądza, choć zyski jednych grup społecznych wynikające z takich działań odpowiadają stratom ponoszonym przez inne grupy społeczne. Rozpowszechnione przekonanie o korzyściach płynących z większej podaży pieniądza wydaje się stanowić kolejny wariant mitu zbitej szyby (Bastiat, [1848] 2009). Jest bowiem 
relatywnie łatwo zidentyfikować korzyści pierwszych odbiorców nowych pieniędzy w postaci ich większych wydatków lub wyższych cen dóbr i usług przez nich sprzedawanych. O wiele trudniej jednak zauważyć, że — ze względu na efekt Cantillona - inflacja monetarna powoduje straty u późnych odbiorców nowo wykreowanych pieniędzy: nie można bowiem zaobserwować niezrealizowanego popytu osób, których dochód nie wzrósł w tym samym stopniu co ceny kupowanych przez nie dóbr i usług.

\section{Podsumowanie}

Ze względu na ograniczoną objętość artykułu przedstawiliśmy w nim jedynie najważniejsze wpływy analizy efektu pierwszej rundy do teorii ekonomii, jednak nie wyczerpują one jej wkładu w dziedzinę ekonomii. Efekt Cantillona rozwija także teorię wzrostu gospodarczego, ponieważ pokazuje, że wpływ zwiększenia ilości pieniądza na wzrost gospodarczy zależy od tego, do kogo trafią nowe pieniądze i na co zostaną one przeznaczone: czy na konsumpcję, czy na oszczędności.

Ponadto analiza efektu pierwszej rundy stanowi ważny wkład do teorii wydatków inwestycyjnych, ponieważ zwraca uwagę na to, że dla przebiegu cyklu koniunkturalnego i realizacji efektu Cantillona znaczenie ma nie tylko sam wolumen inwestycji, ale także ich struktura oraz zmiany w nich zachodzące. Przykładowo, inwestycje w maszyny i oprogramowanie będą inaczej oddziaływać na wzrost gospodarczy i zjawiska koniunkturalne niż inwestycje w budynki i budowle, co pokazuje, że to, w jaki sposób pożyczkobiorcy wydają wykreowane przez banki komercyjne (czy inne instytucje finansowe) i następnie pożyczone im pieniądze, ma istotne znaczenie dla gospodarki.

Poza tym efekt pierwszej rundy może wzbogacić analizę komparatywną systemów ekonomicznych poprzez zwrócenie uwagi na różnice między sposobami wzrostu podaży pieniądza (czy też mechanizmem transmisji monetarnej) w systemach, w których podstawą finansowania są banki oraz w systemach, w których podstawą finansowania jest rynek kapitałowy.

Efekt Cantillona rozwija także teorię długu publicznego oraz wskazuje na niezwykle ważne związki pomiędzy polityką monetarną a fiskalną, które często są pomijane przez ekonomistów. Analiza emisji długu publicznego i wzrostu podaży pieniądza w duchu Cantillona pokazuje, że emisja długu publicznego w obecnym systemie monetarnym jest inflacjogenna, to znaczy prowadzi do wzrostu podaży pieniądza i wszystkich związanych z tym konsekwencji gospodarczych. A zatem, wbrew ekwiwalencji ricardiańskiej, znaczenie ma to, czy rząd finansuje swoje wydatki za pomocą długu czy podatków. W obecnym systemie monetarnym emisja długu publicznego jest inflacjogenna - co w oczywisty sposób wpiera sektor rządowy — podczas gdy wzrost podatków stanowi jedynie transfer siły nabywczej od podatników do rządu. Efekt Cantillona powoduje zatem, że korzyści sektora 
rządowego wykraczają poza standardowo rozumiany senioraż. Rządy są bowiem jednymi z pierwszych odbiorców nowych pieniędzy, a zatem mogą nabywać dobra i usługi po jeszcze niezmienionych (nie całkowicie dostosowanych) cenach. Zatem skupianie się na ogólnym poziomie cen w analizach dotyczących renty emisyjnej i podatku inflacyjnego nie uwzględnia należycie redystrybucji zachodzącej od sektora prywatnego do sektora rządowego na skutek efektu Cantillona.

Jak zatem widać, artykuł pokazuje, że efekt pierwszej rundy jest niezwykle istotnym zjawiskiem gospodarczym, którego analiza znacznie rozwija teorie ekonomiczne - zarówno te przedstawione przez ekonomię głównego nurtu, jak i szkołę austriacką, która, choć uwzględnia efekt Cantillona w swoim dorobku, to i tak znacznie zyskałaby na jego dokładniejszej i bardziej systematyczne analizie. Badanie wzrostu podaży pieniądza, przeprowadzane w duchu Cantillona, stanowi ważne ramy analityczne, które umożliwiają rozwinięcie wielu subdziedzin ekonomii i lepsze zrozumienie procesów gospodarczych. Analiza efektu Cantillona stanowi przede wszystkim ważny głos w debacie na temat roli czynników pieniężnych w gospodarce, wykazując niedostatki ilościowej teorii pieniądza (w jej najprostszym, mechanistycznym ujęciu) i pokazując, że pieniądz nie jest neutralny nawet w długim okresie. Efekt pierwszej rundy, zgodnie z którym wzrost podaży pieniądza nie prowadzi do równomiernych zmian wszystkich cen, lecz do istotnych zmian w strukturze relatywnych cen i wynikających z tego zaburzeń w strukturze produkcji, rozwija także teorię cyklu koniunkturalnego i teorię baniek cenowych.

Efekt Cantillona uwypukla redystrybucyjny charakter inflacji monetarnej. Analiza efektu pierwszej rundy pokazuje, że wzrost podaży pieniądza prowadzi do redystrybucji dochodu i majątku, która może dodatkowo zwiększać nierówności dochodowo-majątkowe. Zatem za wzrost nierówności dochodowo-majątkowych obserwowanych w krajach OECD od lat 70. ubiegłego wieku (OECD, 2011) może częściowo odpowiadać inflacja monetarna. Jest to ważny wniosek wzbogacający nasze rozumienie skutków polityki monetarnej oraz zjawisk koniunkturalnych, jak również teorię inflacji oraz teorię podziału dochodu i nierówności dochodowo-majątkowych.

Bardziej zdezagregowane badanie kreacji nowych pieniędzy i kredytu w duchu analizy Cantillona rozwija także teorię bankowości i bankowości centralnej, pokazując, że znaczenie dla gospodarki ma nie tylko sam wzrost podaży pieniądza, ale także sposób, w jaki się on dokonuje. Dokładniejsza analiza zmian w strukturze bilansów banków komercyjnych i centralnych mogłaby zwiększyć nasze rozumienie tzw. wtórnych cech cykli koniunkturalnych i przyczynić się do powstania systematycznej klasyfikacji cykli koniunkturalnych ze względu na dominujący kanał ekspansji kredytowej (sposób wprowadzania nowych pieniędzy do gospodarki przez banki).

Publikacja wskazuje na wiele negatywnych skutków (nierynkowej) inflacji monetarnej, a zwłaszcza ekspansji kredytowej, takich jak cykle koniunkturalne, odrywanie się cen aktywów od ich wartości fundamentalnych, międzynarodowy 
efekt rozprzestrzeniania się wzrostu podaży pieniądza i kredytu, redystrybucja dochodu (powiększająca nierówności dochodowo-majątkowe). Badanie efektu Cantillona rozwija także teorię wyboru publicznego, pomagając zrozumieć wiele aspektów polityki monetarnej, w tym poparcie dla zwiększania podaży pieniądza, mimo wszystkich negatywnych efektów z tym związanych. Analiza efektu pierwszej rundy wzbogaca także literaturę na temat wzrostu gospodarczego, wydatków inwestycyjnych, analizy komparatywnej systemów ekonomicznych, polityki fiskalnej i długu publicznego oraz ograniczeń polityki pieniężno-kredytowej realizowanej przez banki centralne i banki komercyjne, ponieważ nieuwzględnianie efektu pierwszej rundy przez banki centralne i regulatorów systemu finansowego prowadzi do zbyt luźnej polityki monetarnej i zbyt ekspansywnej kreacji kredytu.

\section{Bibliografia}

Adalid R., Detken C. (2007), Liquidity Shocks and Asset Price Boom/Bust Cycles, „European Central Bank Working Paper Series", nr 732, luty.

Bastiat F. ([1848] 2003), Co widać i czego nie widać, przeł. Piotr Stachura, Lublin-Rzeszów.

Bauer P., Yamey B. (1983), Foreign aid: what is at stake, [w:] The Third World, ed. W. Scott Thompson, San Francisco.

Blaug M. (2000), Teoria ekonomii: ujęcie retrospektywne, wyd. 2, przeł. I. Budzyńska, Warszawa.

Bordo M.D., Helbling T.F. (2010), International Business Cycle Synchronization in Historical Perspective, „NBER Working Paper Series”, nr 16103, czerwiec.

Bordo M.D., Landon-Lane J. (2013), Does Expansionary Monetary Policy Cause Asset Price Booms; Some Historical and Empirical Evidence, „NBER Working Paper Series”, nr 19585.

Bordo M.D., Wheelock D.C. (2004), Monetary Policy and Asset Prices: A Look Back at Past U.S. Stock Market Booms, „NBER Working Paper”, nr 10704.

Borio C., Filardo A. (2007), Globalisation and inflation: New cross-country evidence on the global determinants of domestic inflation, „BIS Working Papers”, nr 227, s. 1-48.

Borio C., Lowe P. (2002), Asset prices, financial and monetary stability: exploring the nexus, „BIS Working Papers", nr 114, s. 1-35.

Bowdler Ch., Radia A. (2012), Unconventional monetary policy: the assessment, „Oxford Review of Economic Policy", vol. 28, nr 4, s. 603-621.

Cantillon R. (1755 [1938]), Ogólne rozważania nad naturalnymi prawami handlu, przeł. W. Zawadzki, Warszawa.

Claessens S. et al. (2012), Shadow Banking: Economics and Policy, „I.M.F. Staff Discussion Note”, $\mathrm{nr} \mathrm{SDN} / 12 / 12$.

Erosa A., Ventura G. (2002), On Inflation as a Regressive Tax, „Journal of Monetary Economics”, vol. $49, \mathrm{nr} 4$.

Fischer S., Modigliani F. (1978), Towards an Understanding of the Real Effects and Costs of Inflation, „NBER Working Paper Series”, nr 303.

Friedman M. (1969), The Optimum Quantity of Money, [w:] idem, The Optimum Quantity of Money, Chicago.

Greenwood R., Scharfstein D. (2012), The Growth of Modern Finance, http://ssrn.com/abstra$\mathrm{ct}=2162179$ (dostęp: 4.05.2015).

Hayek F.A. ([1935] 2014a), Ceny i produkcja, [w:] idem, Pieniądz i kryzysy. Dzieła wybrane, t. 1, przeł. M. Zieliński, Warszawa, s. 153-266.

Ekonomia - Wroclaw Economic Review 22/3 (2016)

(C) for this edition by CNS 
Hayek F.A. ([1937] 2014b), Nacjonalizm monetarny i stabilność międzynarodowa, [w:] Pieniądz i kryzysy. Dzieła wybrane, t. 1, przeł. M. Zieliński, Warszawa, s. 267-342.

Hülsmann J.G. (2013), Fiat Money and the Distribution of Incomes and Wealth, „Document de travail du GRANEM", nr 039, luty.

Kumhof M., Rancière R., Winant P. (2013), Inequality, Leverage and Crises: The Case of Endogenous Default, „IMF Working Paper”, nr WP/13/249, s. 1-47.

Jordà Ò., Schularick M., Taylor A. M. (2014), The Great Mortgaging: Housing Finance, Crises, And Business Cycles, „NBER Working Paper Series”, nr 20501, wrzesień.

Laidler D., Parkin M. (1975), Inflation: A Survey, „The Economic Journal”, vol. 85, nr 345, s. 741-809.

McLeay M., Radia A., Thomas R. (2014), Money Creation in the Modern Economy, „Bank of England Quarterly Bulletin", Q1 2014.

Mersch Y. (2014), Monetary Policy and Economic Inequality, „Speech at Corporate Credit Conference", Zurich, 17.10.2014 r., https://www.ecb.europa.eu/press/key/date/2014/html/sp141017_1. en.html (dostęp: 29.04.2015).

Mises L. ([1949] 2007), Ludzkie działanie, przeł. W. Falkowski, Warszawa.

Mishkin F. (2001), The Transmission Mechanism and the Role of Asset Prices in Monetary Policy, „NBER Working Paper Series”, nr 8617, grudzień, s. 1-21.

Morgenstern O. (1972), Thirteen Critical Points in Contemporary Economic Theory: An Interpretation, „Journal of Economic Literature”, vol. 10, nr 4.

O’Driscoll G. Jr., Rizzo M. (1996), The Economics of Time and Ingorance, London, New York.

OECD (2011), An Overview Of Growing Income Inequalities in OECD Countries: Main Findings, [w:] idem, Divided We Stand: Why Inequality Keeps Rising, Paris.

Ostry D., Berg A., Charalambos G.T. (2014), Redistribution, Inequality, and Growth, „IMF Staff Discussion Note", kwiecień.

Piketty T. (2014), Capital in the Twenty-First Century.

Raskin S.B. (2013), Aspects of Inequality in the Recent Business Cycle, 22nd Annual Hyman P. Minsky Conference on the State of the U.S. and World Economies „Building a Financial Structure for a More Stable and Equitable Economy”, New York, 18.04.2013.

Rzońca A. (2014), Kryzys banków centralnych. Skutki stopy procentowej bliskiej zera, Warszawa.

Scherbina A. (2013), Asset Price Bubbles: A Selective Survey, „IMF Working Paper”, nr WP/13/45, s. $1-40$.

Shughart W.F. (b.r.), Public Choice, [w:] The Concise Encyclopedia of Economics, http://www.econlib.org/library/Enc/PublicChoice.html (dostęp: 21.07.2016).

Sieroń A. (2014), Neutralność pieniądza, „Studia Ekonomiczne”, vol. LXXX, nr 1, s. 88-107.

Sieroń A. (2015a), Efekt Cantillona, „Optimum. Studia ekonomiczne”, vol. 74, nr 2, 2015, s. 68-87.

Sieroń A. (2015b), Klasyfikacja efektu Cantillona, „Ekonomia. Wrocław Economic Review”, vol. 21, nr 4, s. 17-41.

Sieron A. (2015c), Disaggregating the Credit Expansion: The Role of Changes in Banks' Asset Structure in the Business Cycle, „Quarterly Journal of Austrian Economics”, vol. 18, no. 3, s. 247-271.

Sieroń A. (2017), Inflation and Income Inequality, „Prague Economic Papers”, artykuł zaakceptowany do publikacji.

Skousen M. (2011), Struktura produkcji. Giełda, kapitat, konsumpcja, przeł. K. Śledziński, Warszawa.

Thornton M. (2006), The Economics of Housing Bubbles, [w:] America's Housing Crisis: A Case of Government Failure, ed. B. Powell, R. Holcombe, Oakland, CA.

Turner A. (2010), What do banks do? Why do credit booms and bust occur and what can public policy do about it?, [w:] The Future of Finance: The LSE Report, London.

Wagner R.E. (1980), Boom and Bust: The Political Economy of Economic Disorder, „The Journal of Libertarian Studies", vol. IV, nr 1.

Wagner R.E. (1986), Central Banking and The Fed: A Publich Choice Perspective, „Cato Journal”, vol. 6, nr 2, jesień, s. 519-543.

Ekonomia - Wroclaw Economic Review 22/3 (2016)

(C) for this edition by CNS 